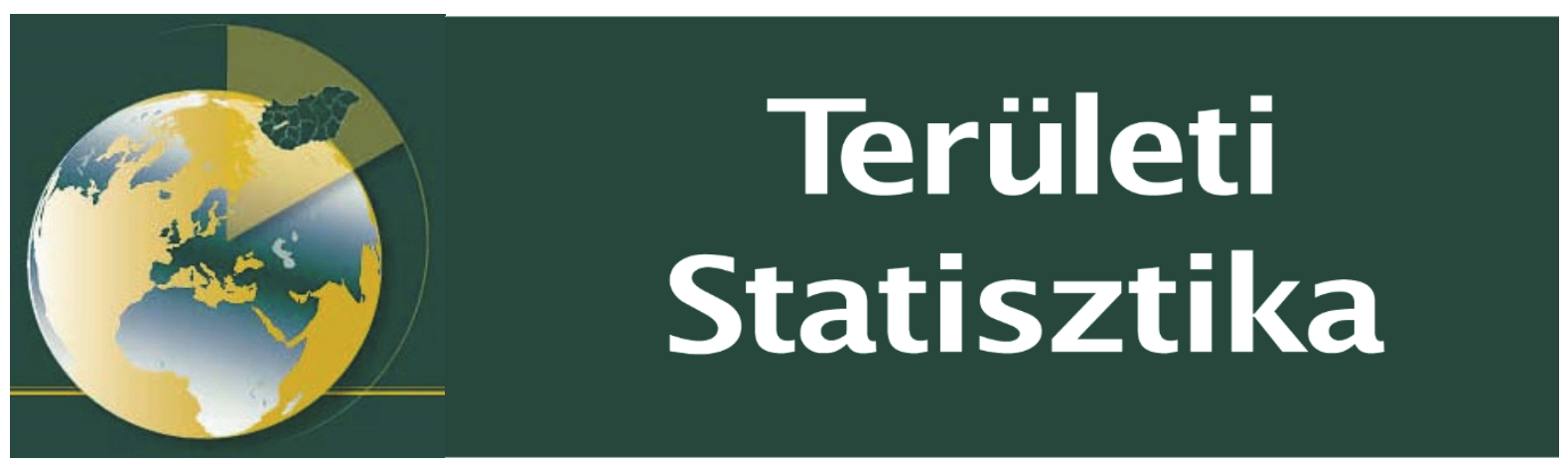

Közzététel: 2019. július 25.

A tanulmány címe:

A magyar gyors növekedésű vállalatok innovációs hálózatának ágens alapú modellje Szerzők:

Varga-Csajkás Anna Pécsi Tudományegyetem, MTA-PTE Innováció és Gazdasági Növekedés

Kutatócsoport, Regionális Innováció- és Vállalkozáskutató Központ (RIERC)

E-mail: csajkas.anna@,ktk.pte.hu

Sebestyén Tamás Pécsi Tudományegyetem KTK, MTA-PTE Innováció és Gazdasági Növekedés

Kutatócsoport, Regionális Innováció- és Vállalkozáskutató Központ (RIERC)

E-mail: sebestyent@,ktk.pte.hu

Varga Attila Pécsi Tudományegyetem KTK, MTA-PTE Innováció és Gazdasági Növekedés

Kutatócsoport, Regionális Innováció- és Vállalkozáskutató Központ (RIERC)

E-mail:vargaa@ktk.pte.hu

https://doi.org/10.15196/TS590404

Az alábbi feltételek érvényesek minden, a Központi Statisztikai Hivatal (a továbbiakban: KSH) Területi Statisztika c. folyóiratában (a továbbiakban: Folyóirat) megjelenö tanulmányra. Felhasználó a tanulmány, vagy annak részei felhasználásával egyidejüleg tudomásul veszi a jelen dokumentumban foglalt felhasználási feltételeket, és azokat magára nézve kötelezónek fogadja el. Tudomásul veszi, hogy a jelen feltételek megszegéséböl eredö valamennyi kárért felelösséggel tartozik.

1) A jogszabályi tartalom kivételével a tanulmányok a szerzői jogról szóló 1999. évi LXXVI. törvény (Szjt.) szerint szerzői műnek minősülnek. A szerzői jog jogosultja a KSH.

2) A KSH földrajzi és időbeli korlátozás nélküli, nem kizárólagos, nem átadható, térítésmentes felhasználási jogot biztosít a Felhasználó részére a tanulmány vonatkozásában.

3) A felhasználási jog keretében a Felhasználó jogosult a tanulmány:

a) oktatási és kutatási célú felhasználására (nyilvánosságra hozatalára és továbbítására a

4. pontban foglalt kivétellel) a Folyóirat és a szerző(k) feltüntetésével;

b) tartalmáról összefoglaló készítésére az írott és az elektronikus médiában a Folyóirat és a szerző(k) feltüntetésével;

c) részletének idézésére - az átvevő mű jellege és célja által indokolt terjedelemben és az eredetihez híven - a forrás, valamint az ott megjelölt szerző $(\mathrm{k})$ megnevezésével.

4) A Felhasználó nem jogosult a tanulmány továbbértékesítésére, haszonszerzési célú felhasználására. Ez a korlátozás nem érinti a tanulmány felhasználásával előállított, de az Szjt. szerint önálló szerzői műnek minősülő mű ilyen célú felhasználását.

5) A tanulmány átdolgozása, újra publikálása tilos.

6) A 3. a)-c.) pontban foglaltak alapján a Folyóiratot és a szerző(ke)t az alábbiak szerint kell feltüntetni:

„Forrás: Területi Statisztika c. folyóirat 59. évfolyam 4. számában megjelent, Varga-Csajkás Anna - Sebestyén Tamás Varga Attila által irt A magyar gyors növekedésú vállalatok innovációs hálózatának ágens alapú modellje c. tanulmány”

7) A Folyóiratban megjelenő tanulmányok kutatói véleményeket tükröznek, amelyek nem esnek szükségképpen egybe a KSH, vagy a szerzők által képviselt intézmények hivatalos álláspontjával. 


\section{A magyar gyors növekedésű vállalatok innovációs hálózatának ágens alapú modellje}

\section{An agent-based model of the Hungarian fast-growth firms' innovation network}

Varga-Csajkás Anna

Pécsi Tudományegyetem KTK, MTA-PTE Innováció és Gazdasági Növekedés Kutatócsoport, Regionális Innováció- és Vállalkozáskutató Központ (RIERC) E-mail: csajkas.anna@ktk.pte.hu

\section{Sebestyén Tamás}

Pécsi Tudományegyetem KTK, MTA-PTE Innováció és Gazdasági Növekedés Kutatócsoport, Regionális Innováció- és Vállalkozáskutató Központ (RIERC) E-mail: sebestyent@ktk.pte.hu

Varga Attila

Pécsi Tudományegyetem KTK, MTA-PTE Innováció és Gazdasági Növekedés

Kutatócsoport, Regionális Innováció- és Vállalkozáskutató Központ (RIERC) E-mail:vargaa@ktk.pte.hu

Kulcsszavak: ágens alapú modell, közelség, gazellák, innováció, hálózatok
A közelség különböző dimenzióinak a tudásáramlásban betöltött jelentőségét vizsgáló szakirodalmi háttérre építve és az ágens alapú modellezés módszertanát felhasználva a szerzők létrehoztak egy modellt, amely alkalmas arra, hogy szimulálja a magyar gyors növekedésú vállalatok (gazellák) tudáshálózatának alakulását. A tanulmányban bemutatott ágens alapú modell nemcsak a közelség/távolság különböző típusainak tudáshálózatra való hatását képes megragadni, hanem a társadalmi távolság dinamikus változását is magában foglalja. A felhasznált adatok a magyar high-tech gazellák ego-hálójának kérdőíves felméréséből származnak, aminek előnye, hogy közvetlenül mérhetőek az innovációs kapcsolatok, így mind a formális, mind az informális együttmúködések bevonhatók az elemzésbe. Az ágens alapú szimuláció paramétereit a szerzôk részben egy ökonometriai modell segítségével határozták meg, amelynek eredményei alapján a földrajzi, a társadalmi és a technológiai távolság is hatással van az innovációs célú együttmúködések létrejöttére. A várakozásoknak megfelelōen az eredmények azt mutatták, hogy minél közelebb állnak egymáshoz a szervezetek a különböző dimenziók szerint, annál nagyobb eséllyel fognak együttmúködni. A vizsgált közelségtípusok közül egyedül az intézményi közelség pozitív hatása nem bizonyult szignifikánsnak. Az ágens alapú modellel végzett szakpolitikai szimuláció rámutat arra, hogy ha egy sikeres vállalkozásfejlesztési program hatására új cégek lépnének be egy olyan ágazatba, amely a térség intelligens szakosodási irányához tartozik, akkor az a tudáshálózat sűrúségét is jelentősen növelné. 


\author{
Keywords: \\ agent-based model, \\ proximities, \\ gazelles, \\ innovation, networks
}

Building on previous literature on the role of proximity dimensions in knowledge flows and using the methodology of agent-based modelling, the study introduces an agent-based model that is appropriate for simulating knowledge network formation among fast-growing firms (gazelles). Beyond the effects of various proximity/distance types on knowledge networks, the model includes the dynamic change of social distance. For empirical underpinning of the model, survey data are used on the Hungarian high-tech gazelles' egocentric network. The advantage of the current database is that it contains information about innovation-related cooperation in general, covering both formal and informal links. Part of the agent-based simulation parameters has been determined by an econometric model, the result of which shows that the geographical, social and technological distance has an impact on innovation-related cooperation. As expected, it is found that the closer the firms are in the sense of different dimensions, the higher the chance for cooperation between them. Organizational proximity is the only investigated proximity dimension that is not significant in the analysis. The policy simulation with the agentbased model points out that a successful entrepreneurship policy that increases the number of new firms entering in a sector which is in line with the smart specialization strategy of the region, could significantly increase the density of the knowledge network.

Beküldve: 2019. január 11.

Elfogadva: 2019. május 7.

\section{Bevezetés}

A tanulmány fókuszában a magyar gyors növekedésű cégek (gazellák) és partnereik innovációs célú együttműködéseinek nyomán kialakuló tudáshálózat áll. Innovációs kapcsolat alatt az együttmúködések széles körét értjük, amelybe beletartozik az információcsere, a K+F-kooperáció, a pályázati együttmúködés, az innovációs célú oktatás, de akár az egyéb típusú együttmúködés is. Az adatok a magyar high-tech gazellák ego-hálójának kérdőíves felméréséből származnak, melyben azt is megkérdezték a vizsgált szervezetektől, hogy innovációs tevékenységük során milyen part-

Területi Statisztika, 2019, 59(4): 426-452; DOI: 10.15196/TS590404 
nerekkel múködtek együtt. Az így azonosított kapcsolatok alkotják az innovációs együttmúködések hálózatát, amelyen keresztül megvalósulhat a tudásáramlás. A tanulmány célja, hogy bemutasson egy ágens alapú modellt, amely a szervezetek közötti innovációs együttmúködések alakulását szimulálja a különböző közelség- és távolságdimenziók változása alapján. Tanulmányunkban a Sebestyén és Varga (2019) által megalkotott és az európai régiók szabadalmi együttmúködési hálózatának vizsgálatára alkalmazott ágens alapú modellt gondoljuk tovább és alkalmazzuk a hazai gazellacégek tudáskapcsolatainak elemzésére. Vizsgálataink szakpolitikai relevanciáját az adja, hogy a különböző paramétereket, illetve exogén változókat szakpolitikai eszközökkel is befolyásolni lehet, aminek hatását képes szimulálni a modell.

A szakirodalom széles köre bizonyította, hogy a földrajzi közelség elósegíti az együttmúködések kialakulását, ezáltal a tudás áramlását a gazdaság szereplői között. Ennek egyik legfontosabb oka az, hogy a tudás egy része nem kodifikálható, hanem ún. tacit jellegű, amely csak személyes interakciók útján sajátítható el. A földrajzi közelség kedvező hatásainak vizsgálata nagy hagyományokkal rendelkezik, már Marshall (1920/1890) rámutatott a gazdasági tevékenységek térbeli tömörülésének pozitív extern hatásaira. Az utóbbi egy-két évtizedben azonban felvetődött a kérdés, hogy ez valóban csak a földrajzi közelségnek köszönhető, vagy azért áramlik könynyebben a tudás két szereplő között, mert azok más szempontból is közel állnak egymáshoz. A közös ismeretek, a hasonló szokások, a személyes ismeretségek sokszor átfedésben vannak a földrajzi közelséggel, mégis egészen más a tartalmuk, ezért érdemes külön-külön azt is megvizsgálni, hogy ezek milyen hatással vannak a tudáshálózatok alakulására. Boschma (2005) szintetizáló művében összegzi a különböző közelségdimenziók irodalmát, és rámutat ezek együttes vizsgálatának fontosságára. Megállapítása szerint a térbeli közelség sem nem szükséges, sem nem elégséges feltétele az egymástól való tanulásnak. A közelség más formái a földrajzi közelség kiegészítői, illetve helyettesítői lehetnek. Az elmúlt években számos empirikus elemzés foglalkozott a közelség különböző vetületeivel (többek között Autant-Bernard et al. 2007, Cantner-Meder 2007, Broekel-Boschma 2012, D’Este et al. 2013, Marrocu et al. 2013, Cassi-Plunket 2015, Usai et al. 2017, Capone-Lazzeretti 2018, Gui et al. 2018), amelyek bizonyították ezek jelentőségét az együttmúködések kialakulásában, ezáltal a tudás áramlásában. ${ }^{1}$ A kognitív vagy technológiai közelség segítheti a kapcsolatok kialakulását, mivel az együttmúködéshez szükséges egy bizonyos szintű közös ismerethalmaz. Ahhoz viszont elég eltérőnek kell lenniük az ismereteknek, hogy érdekeltek legyenek a felek az együttmúködésben. A társadalmi közelség jelentôsége abban rejlik, hogy a személyes kapcsolatok segítik a bizalom kialakulását, és csökkentik annak kockázatát, hogy a másik fél opportunista módon viselkedjen. Az intézményi közelség - a hasonló szabályok és szokások miatt - a kapcsolatok könnyebb menedzselése által segitheti eló a kooperációt és ezáltal a tudásáramlást. Tanulmányunk alapvetően három ponton járul hozzá a közelségdimenziók és az

\footnotetext{
${ }^{1}$ Hau-Horváth és Horváth (2014) metaelemzésében megtalálható ezek összefoglalása.
}

Területi Statisztika, 2019, 59(4): 426-452; DOI: 10.15196/TS590404 
innovációs hálózatok alakulásának irodalmához. Számos tanulmány foglalkozik ugyanis a különböző közelségtípusok innovációs együttmúködésekben betöltött szerepével, viszont ezekben általában a formális kapcsolatokra koncentrálnak, jellemzően statikus szemléletűek és ritkán jelenik meg bennük szakpolitikai elemzés. Ezzel szemben dinamikus megközelítést alkalmazva - a formális együttmúködéseken felül az informális kapcsolatokat is figyelembe véve - a szakpolitika számára is releváns elemzés végezhető el.

A tudáshálózatok modellezésében a formális együttmúködésekre irányuló fokozott figyelem elsősorban az adatok elérhetőségével magyarázható. A közös szabadalmak, a publikációk és az uniós keretprogramok jól dokumentált együttmúködési formák, ezért hatékonyan lehet alkalmazni őket kvantitatív elemzésekhez (például Varga-Sebestyén 2017). Az informális kapcsolatok ennél nehezebben számszerúsíthetők, mivel kérdőíves felmérést igényelnek, de erre is van példa (Capone-Lazzeretti 2018). A közelség együttmúködésekre való hatásának vizsgálatában többnyire statisztikai, ökonometriai módszereket alkalmaznak, amelyekben gyakran statikus szemlélet érvényesül. Ez annak ellenére van így, hogy Balland és szerzőtársai (2014) felhívják a figyelmet arra, hogy nemcsak a különböző értelemben vett közelség hat a tudáshálózatok kialakulására, hanem a hálózatok is visszahatnak a közelségre. Az utóbbi időben azonban dinamikus elemzések is születtek, amelyekben a hálózatok időbeli alakulását (evolúcióját) is modellezik (Balland 2012, Gui et al. 2018). Ezekben sem jelenik meg azonban a közelség és a tudáshálózat egymásra való hatása, hanem exogén változóként tekintenek a közelségre, és azzal magyarázzák a hálózat alakulását. Modellünkben a társadalmi távolság ezzel szemben endogén módon alakul, hasonlóan Sebestyén és Varga (2019), valamint Hau-Horváth és szerzőtársai (2016) tanulmányához. Ez utóbbi tanulmányokban ugyan a tudáshálózatok dinamikus alakulását modellezik, de nem szervezetközi, hanem régiók közötti együttmúködéseket vizsgálnak, és a formális együttmúködések egy speciális körére, a keretprogram-együttmúködésekre koncentrálnak. Kevés példa van továbbá arra, hogy szakpolitikai szimulációkat végeztek volna a közelségdimenziók együttmúködési hálózatban betöltött szerepével kapcsolatban. A számítógépes szimulációra épülő ágens alapú modellezés viszont lehetővé teszi a különböző szakpolitikai forgatókönyvek összehasonlítását, amelyre egy példát is bemutatunk a tanulmány végén.

Elsőként Birch és Medoff (1994) mutatott rá arra, hogy viszonylag kevés, gyors növekedésú vállalat, ún. gazella felelős az új munkahelyek nagy részéért, miközben a vállalati populáció többségét a „kisegerek” és az „elefántok” alkotják. Az előbbiek olyan kisvállalatok, amelyek nem képesek vagy nem törekszenek a növekedésre, az utóbbiak pedig nagyvállalatok, amelyekre lassúbb növekedés jellemző. Kis számuk és nagy gazdasági hatásuk miatt fontos tehát kiemelten foglalkozni a gazellákkal, és alaposabban megismerni a viselkedésüket.

Általánosan elterjedt nézet, hogy a kis- és középvállalkozások számára előnyös a hálózatosodás, mivel így olyan erőforrásokhoz, többek között tudáshoz juthatnak, amelyek egyébként nem lennének számukra elérhetőek. Ez a pozitív kapcsolat, ha

Területi Statisztika, 2019, 59(4): 426-452; DOI: 10.15196/TS590404 
nem is minden mérési módszer alapján, de a legtöbb esetben empirikusan is kimutatható. Schoonjans és szerzőtársai (2013) azt találták, hogy a flamand cégek közötti formális üzleti hálózatokban való részvétel pozitívan hat a vállalatok hozzáadott értékére és eszközeire, a foglalkoztatást viszont nem növeli szignifikánsan. Havnes és Senneseth (2001) a növekedés mérésére használt három mutató közül csak a piac kiterjedtségének esetében talált pozitív összefüggést a hálózatosodás és a növekedés között. Zeng és szerzőtársai (2010) kínai kis- és középvállalatokon végzett elemzésükben kifejezetten az innovációra való hatást vizsgálták, és arra a következtetésre jutottak, hogy a vállalatok egymás közötti kooperációjának van a legnagyobb pozitív hatása az innovációs teljesítményre, de emellett mind a közvetítő intézményekkel, mind a kutatóintézetekkel való együttmúködés is kedvezően hat rá. Lechner és Dowling (2003) kvalitatív elemzést végzett a gyors növekedésú vállalkozások egohálóját vizsgálva, amelyben a különböző típusú hálózatok növekedésben betöltött szerepét mutatták be esettanulmányokban. Feltáró jellegú kutatásukban megállapították, hogy az évek során minden vállalat kialakítja a különböző típusú kapcsolatrendszereknek egy olyan kombinációját, ami a fejlődés adott szakaszaiban a legnagyobb mértékben elősegíti a növekedést. Rámutattak arra, hogy a tudás, az innováció és a technológia hálózatai, több más jellegú hálózattal ellentétben, a fejlődés minden szintjén fontosak, de a különböző szinteken más és más problémákat vetnek fel. Az induló szakaszban még nincs hozzáférésük a cégnek az ilyen hálózatokhoz, késóbb viszont hatalmas költségekkel jár a kapcsolatok fenntartása.

Az elmúlt tíz évben több, a magyar gazellák jellemzőinek feltárására irányuló kutatást is végeztek (Papanek 2010, Némethné 2010, Csapó 2011, Békés-Muraközi 2012, Szerb et al. 2017). A legfrissebb kutatások rámutattak arra, hogy a magyar gyors növekedésű vállalatok nehezen tipizálhatóak, és sokszor nem jellemezhetőek olyan pozitív tulajdonságokkal, mint az innovativitás, az exportorientáltság vagy a nagyobb versenyképesség, amelyek a nemzetközi szakirodalom szerint a gyors növekedéshez kötődnek (Szerb et al. 2017).

A tanulmány további része a következőképpen épül fel: először bemutatjuk a magyar gazellák innovációs kapcsolatait tartalmazó adatbázist, majd ismertetjük az ágens alapú modell múködési mechanizmusait. Ezt követi a modell paramétereinek meghatározása, továbbá egy példán keresztül annak illusztrálása, hogy milyen jellegú szakpolitikai szimulációk elvégzésére alkalmas a modell. A tanulmány a következtetések levonásával és a korlátok ismertetésével zárul.

\section{Az adatok bemutatása}

A tanulmányban felhasznált adatok a Varga Attila vezetésével megvalósított „Magyar gazellacégek együttmúködési hajlandóságának vizsgálata” elnevezésú kérdőíves felmérés eredményeiből származnak. Az MTA-PTE Innováció és Gazdasági Növekedés Kutatócsoport $(2014,2016)$ kutatási jelentései tartalmazzák a háromkörös

Területi Statisztika, 2019, 59(4): 426-452; DOI: 10.15196/TS590404 
adatfelvétel részletes eredményeit. Az első kör a magyarországi gyors növekedésű vállalatok tulajdonságait tárta fel. A második körben azonosították a gazellák innovációs együttmúködő partnereit, majd a harmadik körben ezeket az elsődleges partnereket kérték meg partnerszervezeteik megnevezésére, akikből azután a gazellák másodlagos partnerei lettek. A kérdőíves felvétel eredményeit a szervezetek egyéb adataival egészítettük ki, amelyet a http://e-beszamolo.im.gov.hu oldalról a vállalatok beszámolóiból, illetve a szervezetek honlapjáról gyújtöttünk. A kutatás során alkalmazott definíció szerint egy cég gazellának számít, ha esetében a következő két feltétel teljesül:

1. Az értékesítés nettó árbevételének átlagos éves növekedési üteme három egymást követő éven keresztül meghaladja a $20 \%$-ot, illetve

2. az adott évben legalább 5 főt foglalkoztat.

Mivel a hazai gyors növekedésű vállalatok felmérése volt a cél, ezért csak a magyarországi székhelyú, minimum 75\%-ban magyar tulajdonú múködő vállalatok kerültek be a mintába. Az Opten Informatikai Kft. által szolgáltatott adatállományban 4037 cég felelt meg ennek a definíciónak. Ebből az alapsokaságból az agglomerációs térségek szerint területileg, valamint - a gazdasági tevékenységek egységes ágazati osztályozási rendszere (TEÁOR) szerinti besorolás alapján - ágazatilag is rétegzett mintavétel eredményeként 404 vállalat szerepelt a mintában. Szerb és szerzőtársai (2017) részletesen ismertetik az alapsokaság meghatározásának szempontjait és a mintavétel módját. Tanulmányukban bemutatják a kérdőíves felmérés eredményeit, így a magyar gazellák általános jellemzőit, a kérdőívet kitöltő tulajdonosok/üzletvezetők tulajdonságait, a vizsgált cégek innovációs tevékenységgel kapcsolatos jellemzőit és exportorientációjuk mértékét. 12 klaszterképző változó alapján a gazellák 7 csoportját különítik el, melyek eltérő növekedési stratégiákat követnek.

Ezt a 404 elemû́ mintát a kutatás következő szakaszában két szempont szerint szúkítették: egyrészt kiszúrték azokat a vállalatokat, amelyek nem számoltak be semmiféle innovációs kapcsolatról, másrészt azokat is, amelyek nem tartoztak a high-tech ágazatokba. A második körben egy 80 elemből álló, szúkített mintán azonosították e szervezetek innovációs partnereit. Ennek során megkérdezték, hogy az innovációs tevékenységükben milyen külső partnerekkel működtek együtt. Minden megnevezett partner esetén a válaszadók kitöltöttek egy-egy partneradatlapot, amely az adott partnerre és a kapcsolat jellemzőire vonatkozó kérdéseket tartalmazott. Az e körben vizsgált 80 high-tech gazellából végül 55 adott értékelhető választ. A megkérdezett gazellák 94 szervezetet azonosítottak, akiket a gazellák elsődleges partnereinek nevezünk. A harmadik körben őket kérdezték meg, és közülük 53-an válaszoltak a feltett kérdésekre. A válaszadók összesen 183 partnerkapcsolatról számoltak be. Az így megnevezett szervezetek alkotják a gazellák másodlagos partnereinek csoportját. Az ismertetett módszerből fakadóan a gazellákról és elsődleges partnereikről részletes információkkal rendelkezünk, amelyeket a következőkben röviden összefoglalunk.

Területi Statisztika, 2019, 59(4): 426-452; DOI: 10.15196/TS590404 
A kérdőíves felmérésből kiderült, hogy a high-tech gazellák elsődleges partnereinek 40\%-a nem profitorientált szervezet. A második körben szereplő cégek mindegyikét a rendszerváltás után alapították, míg a harmadik kör szervezeteinek egyötödét 1989 előtt. A létszámadatok alapján megállapítható, hogy a második körben megkérdezett high-tech gazellák közel háromnegyede 25-nél kevesebb főt foglalkoztatott, és az elsődleges partnereiknél is ez a létszám-kategória volt a leggyakoribb. A felsőfokú végzettséggel rendelkező munkatársak átlagos száma a legtöbb esetben 20-30 fő közötti, de az egyetemek és néhány nagyobb vállalat esetén 100 főnél több volt. A megkérdezettek többsége egyáltalán nem, illetve csak szerény mértékủ létszámbővüléssel számolt. A második körben megkérdezett gazellák közül csak néhányan rendelkeztek 1 milliárd forintnál nagyobb árbevétellel, a harmadik körben már valamivel több ilyen szervezet volt, de mindkét körben jelentős volt a 100 millió forintnál kisebb árbevétellel rendelkező szervezetek aránya. Mindkét körben volt néhány válaszadó, aki nagyarányú (100\% feletti) árbevétel-növekedést tervezett a következő 5 évben, de alapvetően a szerényebb fejlődés prognosztizálása jellemezte a megkérdezett szervezeteket. A felmérés résztvevőinek többsége csak belföldön értékesítette termékeit, illetve szolgáltatásait. Az árbevétel forrásait tekintve is hasonlóak az említett két körben megkérdezett szervezetek, mely szerint az árbevétel legnagyobb része üzleti vállalkozásból származott, amit a lakossági és a pályázati bevétel követett.

A kitöltött partneradatlapok alapján egy irányított gráfot kaptunk, melynek segítségével azonosítható volt a jelölő szervezet és a partnerszervezet, de a továbbiakban irányítatlan gráfnak tekintettük a gazellák kapcsolati hálóját. Ha az egyik fél azt nyilatkozta, hogy közöttük van kapcsolat, akkor annak irányát nem értelmeztük, csak rögzítettük, hogy létrejött az együttmúködés. A gazellák és az elsődleges, illetve a másodlagos partnereik hálózatát így egy szimmetrikus mátrixszal írhattuk le, melynek elemei a két szervezet közötti kapcsolatot reprezentálták. A mátrix eleme 1, ha van kapcsolat a két szervezet között és 0 , ha nincs.

A felmérés során azonosított szervezetek között elsősorban cégek szerepeltek, de oktatási intézményeket és egyéb szervezeteket (például iparkamarákat) is megneveztek partnerként. Többségében hazai szervezetek alkotják a gazellák elsődleges és másodlagos partnereinek csoportját, de külföldiek is szerepelnek közöttük. Mivel a kérdőív adatain felül kiegészítő információkra volt szükség a modell alkalmazásához, és ezek elérhetôsége, valamint a változók értelmezése nem volt megoldható minden szervezettípus esetén, ezért leszúkítettük a partnerek körét a magyar vállalatokra és felsőoktatási intézményekre. A felsőoktatási intézmények esetén a megkérdezettek különböző szervezeti szinteken azonosították a partnereiket (intézet, tanszék, kar, egyetem), amelyeket az összehasonlíthatóság érdekében aggregáltunk az egyetem szintjére. Így összesen 207 ágens maradt a vizsgálatban, melyek közül 102 egy összefüggô hálózatot alkotott, míg a többi szervezet kisebb különálló csoportokban, vagy izoláltan helyezkedett el, az 1. ábrán bemutatott módon.

Területi Statisztika, 2019, 59(4): 426-452; DOI: 10.15196/TS590404 
A high-tech gazellák innovációs hálózata

1. ábra

Innovation network of high-tech gazelles

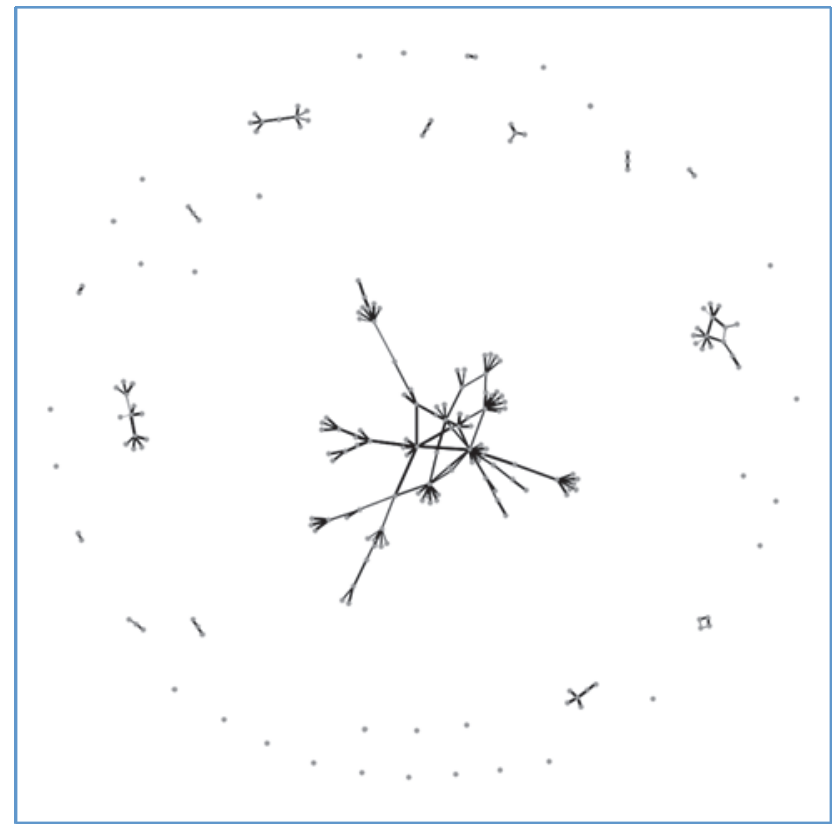

A kapcsolat tartalmát a kérdőívben elöre definiált kategóriák szerint adhatták meg a megkérdezett szervezetek képviselői. Az eredményekből kiderült, hogy a legtöbb esetben információcsere volt a kapcsolat tartalma, K+F-kooperáció vagy pályázati együttmúködés ennél kisebb számban, innovációs célú oktatás pedig kifejezetten ritkán fordult elő. Az esetek többségében egyszerre töltik be információforrás és együttmúködő partner szerepét a megnevezett szervezetek, amiből arra következtethetünk, hogy ez a két funkció nem válik el élesen egymástól a gyakorlatban. A high-tech gazellák és az elsődleges partnerek esetén is a kapcsolat kialakításának két legjellemzőbb motivációja a piacra lépés, a piaci részesedés növelése, a piaccal kapcsolatos információk beszerzése és a termék- vagy technológiafejlesztés volt. Mindkét körben a nevesített partnerek többsége ügyfél/vásárló vagy beszállító volt. Versenytársak, tanácsadó cégek, vállalatcsoporton belüli más vállalatok, felsőoktatási intézmények, állami vagy egyéb kutatóintézetek kisebb számban voltak jelen. Csak a magyarországi székhelyű szervezeteket tekintve az átlagos távolság közúton 100 kilométernél kisebb volt, és leggyakrabban az azonos településen múködő szervezetek létesítettek kapcsolatot egymással. Mindkét körben a 2000 után létrejött kapcsolatok voltak többségben, és ezen belül is az utolsó 5 évben létesített kapcsolatok fordultak elő leggyakrabban. A kapcsolat kialakítására és fenntartására fordított erőforrások jelentőségéről megállapítható, hogy a partner keresése során felmerülő

Területi Statisztika, 2019, 59(4): 426-452; DOI: 10.15196/TS590404 
ráfordításokat többnyire nem tekintik meghatározónak sem a gazellák, sem az elsődleges partnerek. A kapcsolat fenntartására fordított időt és emberi erőforrást viszont jelentősnek tartják. A többi tényezőt (például tárgyalás, kapcsolattartás, vitarendezés, kockázatok, menedzselés) alapvetően nem tekintik fontosnak. A kapcsolatok több mint fele írásban is rögzített együttmúködés, de viszonylag nagy számban jelennek meg az informális kapcsolatok is.

A tanulmányban bemutatott ágens alapú modell, valamint a paraméterek meghatározásához használt ökonometriai becslés alapja a társadalmi térben való elhelyezkedés, amit az innovációs együttmúködési hálózatban elfoglalt pozícióból származtattunk. A 102 csúcsból álló összefüggő hálózathoz nem kapcsolódó ágensek esetén a legtöbb szervezettel szemben végtelen hosszú hálózati távolságot kaptunk, ami miatt esetükben nem tudtuk meghatározni a társadalmi térben elfoglalt pozíciót, ezért a továbbiakban csak az összefüggő részt vettük figyelembe.

\section{Az ágens alapú modell}

\section{A módszer válaszłásának indoklása és a modell alapelvei}

A hálózatok kialakulásával foglalkozó modelleket három csoportra oszthatjuk: a random gráf modellekre, a hálózatok kialakulásának stratégiai modelljeire, valamint az ágens alapú modellekre. Ezek jelentős mértékben eltérnek egymástól a tekintetben, hogy mennyire absztrakt jellegűek, ezáltal milyen elemzésekre alkalmasak. A random gráf modellek (Erdős-Rényi 1959, Watts-Strogatz 1998, Barabási-Albert 1999) a hálózatok kialakulásának valószínűségi megközelítésére épülnek. Esetükben a hálózati kapcsolatok véletlenszerúen jönnek létre, de nem feltétlenül függetlenek egymástól, valamint a csomópontok tulajdonságaitól. E modellek alapvetően a hálózatok topológiájában megfigyelhető jelenségek magyarázatára alkalmasak.

A hálózatok kialakulásának stratégiai modelljeit Jackson (2005) tekinti át. Ezekben a modellekben a létrejövő hálózati struktúra az egyének stratégiai interakcióinak eredménye. Ugyan megjelennek az egyéni döntések is bennük, de a modellek stilizáltak maradnak: arra tervezték őket, hogy egyes megfigyelt tulajdonságokat magyarázzanak, és a segítségükkel elemezni lehessen a hálózatok stabilitását és hatékonyságát.

A hálózatok kialakulását is magában foglaló modellek harmadik csoportját alkotó ágens alapú innovációs modellek képesek a heterogén szereplők interakciói során kialakuló jelenségek szimulálására. Számunkra ez a megközelítés a leginkább megfelelő, mivel lehetőséget teremt a modellek empirikus adatokkal való feltöltésére, ezáltal gyakorlati szempontból releváns szakpolitikai hatáselemzések elvégzésére. Ide sorolható a SKIN-modell (Gilbert et al. 2001, Ahrweiler et al. 2004, Pyka et al. 2007) és az arra épülő VISIBLE szimulációs platform (Pyka et al. 2018), amelyekre alapozva számos empirikusan kalibrált hatáselemző jellegú munka is született (Korber-Paier 2011, 2013, Paier et al. 2017). Ezekre jellemző, hogy a teljes innová-

Területi Statisztika, 2019, 59(4): 426-452; DOI: 10.15196/TS590404 
ciós rendszert ragadják meg, melynek csak egy része az innovációs kapcsolatok kialakulásának modellezése. Ide sorolhatók még egyéb ágens alapú innovációs modellek is, amelyeknek szintén része a kapcsolatok kialakulása, de ennél tágabb a vizsgálódásuk fókusza (Pyka-Saviotti 2002, Heshmati-Lens-Cesar 2013). A tanulmányban alkalmazott modell ezek közül Heshmati és Lens-Cesar (2013) megközelítéséhez áll a legközelebb, a társadalmi tér reprezentációja kapcsán.

A modell múködési elvei megegyeznek a Sebestyén és Varga (2019) által általánosan megfogalmazott mechanizmusokkal. Az európai régiók közötti együttmúködési hálózatra hozták létre a modellt, amelyben az ágensek maguk a régiók, és az európai uniós keretprogramokban való közös részvétel jelenti a kapcsolatot közöttük. Jelen tanulmányban ennek a modellnek a magyar high-tech gazellák innovációs hálózatára adaptált változatát mutatjuk be. A modell legfontosabb elemei a társadalmi tér, amelyben az ágensek elhelyezkednek és mozognak, valamint a gravitációs vonzerő és az ellenerő, amelyek alapvetően meghatározzák az ágensek mozgásának irányát. Ezen kívül fontos jellemzője a modellnek, hogy az ágensek heterogén tulajdonságokkal rendelkeznek, ami szintén befolyásolja a viselkedésüket, ezáltal a kialakuló hálózatot.

Az ágensek mozgása két komponensből, a mozgás irányából és sebességéből tevődik össze. Az irány a gravitáció elvén meghatározott vonzerô és az azt ellensúlyozó, a kapcsolatok kialakításának költségét reprezentáló ellenerő kettőse által meghatározott célpozícióból származik. Ezt adottnak tekintve az ágensspecifikus konstans sebesség határozza meg, hogy az egyes szereplők mennyit haladnak a társadalmi térben egy időegység alatt.

\section{A célpozíció meghatározása}

Elsőként elhelyezzük az ágenseket a társadalmi teret reprezentáló kétdimenziós absztrakt térben az innovációs együttmúködési hálózatban elfoglalt pozíciójuk alapján. A hálózati távolságot a két csúcs közötti legrövidebb út hosszával mérjük, amiből viszont nem származtatható egyértelmúen az euklideszi távolság. Ezért a többdimenziós skálázás (multidimensional scaling - MDS) módszerét felhasználva úgy helyezzük el az ágenseket a kétdimenziós térben, hogy a közöttük lévő euklideszi távolság a lehető legpontosabban megfeleljen a hálózati távolságnak. Így a társadalmi térben azok fognak közelebb elhelyezkedni egymáshoz, akik között a hálózati távolság is alacsony. A dimenziószám csökkentésére azért van szükség, mert az ágensek a szimuláció minden időegységében elmozdulnak a megcélzott pozíciójuk irányába. Ennek a mozgásnak az értelmezése és kiszámítása két dimenzióban könnyen kivitelezhetô, magasabb dimenziószám esetén viszont túlzottan számításigényes lenne. Ebből az alaphelyzetből azzal a céllal indulnak el az ágensek egymás felé, hogy együttmúködő partnereket találjanak innovációs elképzeléseik megvalósításához.

A vonzerő $\left(A_{i j, t}\right)$ meghatározásához a következő gravitációs egyenletet használjuk, amelyben az ágensek tömege $\left(M_{i, t}, M_{j, t}\right)$ mellett a közöttük lévő, különböző érte-

Területi Statisztika, 2019, 59(4): 426-452; DOI: 10.15196/TS590404 
lemben vett közelségek és távolságok szerepelnek. Ide tartozik a földrajzi távolság $\left(G D_{i, j, t}\right)$, a technológiai közelség $\left(T P_{i, j, t}\right)$, a társadalmi távolság $\left(S D_{i, j, t}\right)$ és az intézményi közelség $\left(I P_{i, j, t}\right)$ :

$$
A_{i, j, t}=f\left(M_{i, t}, M_{j, t}, G D_{i, j, t}, T P_{i, j, t}, S D_{i, j, t}, I P_{i, j, t}\right)
$$

A gravitációs elv alapján annál nagyobb a vonzerő két ágens között, minél nagyobb a tömegük, és minél kisebb közöttük a távolság. A közelségdimenziók jelentőségével foglalkozó empirikus irodalomban gyakran megjelenik ez az elv (például Maggioni-Uberti 2009). Az egyes változókhoz tartozó együtthatók a következő fejezetben bemutatott ökonometriai becslésből származnak.

Az egyenlet jobb oldalán egy kivétellel exogén változók szerepelnek, egyedül a társadalmi távolság változik a szimuláció során. A páronkénti vonzerő tehát akkor változik, ha a társadalmi térben elfoglalt pozíciók módosulnak. A társadalmi távolság kezdeti értékét az ágensek kétdimenziós társadalmi térben elfoglalt kezdeti pozíciójából $\left(x_{i, 0}^{1}, x_{i, 0}^{2}\right)$ származtatjuk.

Ezek alapján meghatározhatjuk a kivánt pozíciót a következő képlet segítségével:

$$
y_{i, 1}^{z}=\sum_{j} \frac{A_{i, j, o}}{\sum_{k} A_{i, k, o}} \cdot x_{j, o}^{z}
$$

ahol $z \in(1,2) . A z\left(y_{i, 1}^{1}, y_{i, 1}^{2}\right)$ pár fejezi ki azt a pozíciót, ahová az ágens a vonzerő alapján el kíván jutni, tehát ez a vonzerő iránya.

Mozgásuk során a szervezetek a potenciális partnereknek csak egy részhalmazát veszik figyelembe, mivel azt feltételezzük, hogy túl sok energiát igényelne, ha minden rajtuk kívül álló szervezetet követnének. Ezt fejezi ki a partnerlista hossza $(A P)$, ami azt mutatja meg, hogy hány másik szereplő helyzetét veszik figyelembe mozgásuk irányának meghatározása során.

A gravitációs erô mellett megjelenik az ellenerő, ami a vonzerő irányával ellentétes irányba hat, ezáltal biztosítva a modell stacioner jellegét. Ennek megfelelően az elleneröópozició a következőképpen alakul:

$$
b_{i}^{z}=2 \cdot x_{i, 0}^{z}-y_{i, 1}^{z}
$$

ahol $\mathrm{z} \in(1,2)$. Ez a $\left(b_{i}^{1}, b_{i}^{2}\right)$ pont egy olyan pozíciót határoz meg a társadalmi térben, ami a kiindulóponttól $\left(x_{i, 0}^{1}, x_{i, 0}^{2}\right)$ ugyanolyan távolságra található, mint a kívánt pozíció $\left(y_{i, 1}^{1}, y_{i, 1}^{2}\right)$, de pontosan ellentétes irányban helyezkedik el.

Ezek alapján meghatározható a célpozíció, ami már a vonzerô és az ellenerô együttes figyelembevételével adódik:

$$
l_{i, 1}^{z}=x_{j, 0}^{z}+\left(y_{i, 1}^{z}-x_{j, 0}^{z}\right)+B F P_{i} \cdot\left(b_{i}^{z}-x_{j, 0}^{z}\right)
$$

ahol $z \in(1,2)$. A 4. egyenletből látszik, hogy a célpozíció a vonzerő és az ellenerő vektorösszege. $B F P_{i}$, az ellenerő nagyságát kifejező paraméter 0 és 1 között vehet fel értékeket. $\mathrm{Ha} B F P_{i}=1$, tehát maximális az ellenerő, akkor, abban az esetben, ha nem érkezik sokk a rendszerbe, a célpozíció megegyezik a kiindulóponttal, vagyis egy helyben maradnak az ágensek. Ha $B F P_{i}=0$, akkor azt feltételezzük, hogy a kapcsolat kialakításának és fenntartásának nincs költsége, tehát a célpozíciót csak a vonzerô

Területi Statisztika, 2019, 59(4): 426-452; DOI: 10.15196/TS590404 
határozza meg. Ha 1-nél kisebb az ellenerő, de 0-nál nagyobb, akkor szerepet játszik a célpozíció meghatározásában, de sokk nélkül sem maradnak egy helyben az ágensek. Az ellenerő mértéke az ágensek méretétől függően heterogén módon alakul, tehát ágensenként eltérő, hogy mekkora költséggel jár a kapcsolatok létrehozása és fenntartása. A méret ( $\left.W_{i}\right)$ esetünkben az innovatív tömeg transzformált változata, ahol az átlagos tömeg értéke egyenlő eggyel. Az ellenerő nagysága a következő egyenlettel írható le:

$$
B F P_{i}=(\overline{B F}-B R)+B R \cdot W_{i}
$$

ahol $\overline{B F}$ az átlagos ellenerôt fejezi ki, $B R$ pedig az elaszticitásparaméter, ami azt mutatja meg, hogy hogyan függ az ellenerő az ágens méretétől.

\section{Az ágensek elmozdulása}

A bemutatott célpozíciót azonban nem érik el automatikusan az ágensek, hanem csak közelíteni kezdenek felé, és a sebességüktől függ, hogy egy időszak alatt menynyire jutnak közel hozzá.

Az elmozdulás eredményeként az új pozíció a következőképpen alakul:

$$
x_{i, 2}^{z}=x_{i, 1}^{z}+\frac{S_{i}}{L_{i, 2}} \cdot\left(l_{i, 2}^{z}-x_{i, 1}^{z}\right)
$$

ahol $L_{i, 2}=\sqrt{\left(l_{i, 2}^{1}-l_{i, 1}^{1}\right)^{2}+\left(l_{i, 2}^{2}-l_{i, 1}^{2}\right)^{2}}$ az euklideszi távolság az aktuális és a célpozíció között.

Az ágensek a méretüktől függően eltérő sebességgel haladnak a kétdimenziós társadalmi térben. A mozgásuk sebességének leírásához az ellenerőhöz hasonlóan két paraméter szükséges: az alapparaméter $(\bar{S})$, ami a sebességnek az átlagos szintjét fejezi ki, és az elaszticitásparaméter (SR), ami azt mutatja meg, hogy hogyan függ mozgásuk sebessége a méretüktől. Ezek alapján a sebesség a következő képlettel számítható ki:

$$
S_{i}=(\bar{S}-S R)+S R \cdot W_{i}
$$

Ha $S R$ egyenlő 0 -val, akkor minden ágens azonos sebességgel mozog, ami megegyezik az alapparaméter értékével $(\bar{S})$. Ha $S R$ pozitív, akkor a nagyobb méretű ágensek mozognak gyorsabban, ha pedig negatív, akkor a kisebb méretúek.

Amint az elmozdulás hatására új pozícióba $\left(x_{i, 2}^{1}, x_{i, 2}^{2}\right)$ kerülnek az ágensek, az egymástól való társadalmi távolságuk $\left(S D_{i, j}\right)$ is megváltozik, ami hatással van a páronkénti vonzerőre $\left(A_{i j}\right)$. Ennek következtében a kívánt pozíció is módosul, ami az ellenerôvel való kölcsönhatás eredményeként új célpozícióhoz vezet, ezért az ágensek tovább mozognak. Ez a folyamat addig tart, amíg a rendszer nyugalmi állapotba nem kerül.

Területi Statisztika, 2019, 59(4): 426-452; DOI: 10.15196/TS590404 


\section{A gravitációs egyenlet}

Célunk annak megállapítása, hogy milyen szerepet játszanak a különböző közelségés távolságtípusok az innovációs együttmúködések kialakulásában. Erre azért van szükség, hogy meghatározzuk a modell alapjául szolgáló gravitációs egyenletben szereplő változók hatását. A gravitációs egyenlet változóinak együtthatóit egy ökonometriai modellel becsüljük. A Newton-féle gravitációs törvény eredetileg a fizikai testek közötti vonzerôt írja le, de társadalmi folyamatokban is fellelhetô a tömegvonzás elve. A közgazdaságtan eszköztárába a nemzetközi kereskedelem magyarázata során került be, mivel kézenfekvő összefüggés, hogy míg a nemzetközi kereskedelem volumenét a két ország - bruttó hazai termék (gross domestic product GDP) alapján vett - mérete pozitívan, addig a közöttük lévő távolság negatívan befolyásolja. Ez az analógia átültethető a szervezetközi innovációs együttmúködések kontextusába, ahol a kapcsolat kialakulásának valószínűségét vagy azok erősségét magyarázzuk a tömeg- és a távolságváltozókkal (többek között Maggioni-Uberti 2007, Scherngell-Barber 2009). Azt feltételezzük tehát, hogy minél nagyobb a két szervezet, annál nagyobb valószínűséggel fognak együttmúködni innovációs tevékenységük során, és minél nagyobb közöttük a távolság, annál nehezebb a kapcsolat kialakítása, ezért annál kisebb valószínűséggel múködnek együtt. A távolságot nemcsak földrajzi, hanem technológiai, társadalmi és intézményi dimenzióban is értelmezhetjük. A következőkben előbb bemutatjuk a változókat, majd a paraméterbecslés eredményét.

\section{Eredményváltozó: az innovációs kapcsolatok}

Függő változónak a high-tech gazellák kérdőíves felméréséből nyert innovációs együttmúködéseket (Conn) tekintjük, és ágenspáronként értelmezzük azt. Ebbe a különböző típusú formális és informális innovációs célú kapcsolatok széles köre (információcsere, $\mathrm{K}+\mathrm{F}-\mathrm{kooperáció,} \mathrm{pályázati} \mathrm{együttmúködés,} \mathrm{innovációs} \mathrm{célú} \mathrm{okta-}$ tás) tartozik bele. Mivel a kapcsolatok létét vesszük csak figyelembe, azok szorosságát nem értelmezzük, ezért egy dichotóm változót alkalmazunk, amelynek értéke 1, ha van innovációs együttmúködés a két ágens között, és 0 , ha nincs.

\section{Innovatív tömeg, földrajzi távolság, technológiai és intézményi közelség}

A gravitációs egyenlet alapvetô változója a tömeg, amelyet ebben az esetben innovatív tömegként értelmezünk (InnMass). Éppen ezért nem a cégméretet kifejező szokásos mutatók valamelyikével (árbevétel vagy létszám) közelítjük, hanem a már meglévő innovációs kapcsolatok számával ragadjuk meg a tömeget. Azt feltételezzük tehát, hogy a több kapcsolattal rendelkező szervezetek a jövőben vonzóbbak lesznek.

A földrajzi közelség jelentősége többek között abban áll, hogy a tudás bizonyos elemei nem kodifikálhatók, hanem tacit jellegúek, ezért személyes interakcióra van szükség a tudásátadás érdekében. Annak ellenére, hogy az infokommunikációs esz-

Területi Statisztika, 2019, 59(4): 426-452; DOI: 10.15196/TS590404 
közök fejlődésével lehetővé vált a fizikai kapcsolat nélküli azonnali információcsere, az empirikus tapasztalatok azt mutatják, hogy a földrajzi távolság így is csökkenti az innovációs kapcsolatok kialakulásának valószínúségét. A földrajzi távolságot (GeoDist) a szervezetek székhelyei közötti euklideszi távolsággal mérjük. A hightech gazellák és elsődleges partnereik esetén a székhely címe kiderül a kérdőívekre adott válaszokból, a másodlagos partnerek esetén pedig vagy a postai címet, vagy a honlap címét meg kellett adni, ami alapján azonosítható a székhelyük. Geokódoló program segítségével cím alapján meghatároztuk a szélességi és a hosszúsági koordinátákat, amelyekből euklideszi távolságot számoltunk ${ }^{2}$, és ezt építettük be a regreszsziós modellbe.

A technológiai közelség segítheti a kapcsolatok kialakulását, mivel az együttmúködéshez szükséges egy bizonyos szintú közös ismerethalmaz. Ahhoz viszont elég eltérőnek kell lenniük az ismereteknek, hogy érdekeltek legyenek a felek az együttmúködésben. A technológiai közelség mérésére többnyire a vállalatok szabadalmi portfóliójának átfedésére épülő folytonos indexet használnak (Cantner-Meder 2007, Cassi-Plunket 2015). A szabadalmi adatokra épülő módszer alternatívája a cégek iparági besorolásának figyelembevétele. Ekkor egy kétértékú változó azt fejezi ki, hogy a két szervezet fótevékenysége megegyezik-e a TEÁOR szerint. A módszer finomítható azzal, ha 4 különböző dummy változót vezetünk be aszerint, hogy az 1, 2, 3 vagy 4 jegyú TEÁOR-kódjukban megegyeznek-e a cégek fôtevékenységei (Usai et al. 2017). Mivel a mintában sok olyan szervezet szerepelt, amelyeknek nem volt szabadalmuk, ezért mi az utóbbi megoldást választottuk. A technológiai közelséget tanulmányunkban 4 darab kétértékủ változó fejezi ki. Ennek értelmében, ha a két szervezet főtevékenységének TEÁOR-kódjában mind a 4 számjegy megegyezik (TechD1), akkor nagyon erôs közöttük a technológiai közelség. Ennél gyengébb, ha csak az első 3 (TechD2), illetve 2 számjegyükben azonosak (TechD3), és a leggyengébb, ha csak az első számjegyük egyezik meg (TechD4). Ha egyetlen számjegyük sem azonos, akkor nem állnak közel egymáshoz technológiai értelemben, ezt tekintjük referenciakategóriának, amelyhez viszonyítva értelmezhetjük a 4 dummy változó együtthatóját. Ez a mérési mód lehetőséget biztosít a közelségi paradoxon (Boschma-Frenken 2010) kimutatására, miszerint a technológiai közelség pozitívan hat az együttmúködésekre, de csak egy bizonyos szintig, utána viszont hátráltathatja a közös innovációt. Míg ennek megfelelően a közelség gyengébb szintjét kifejező dummy változók esetén pozitív, addig a nagyon erős közelséget kifejező változók esetén negatív elöjelet várunk.

Az intézményi közelség a hasonló szabályok és szokások miatt a kapcsolatok könnyebb menedzselésével segítheti elő a kooperációt és ezáltal a tudásáramlást. Ennek a közelségdimenziónak a mérése az előbbiekénél kevésbé egységes, amelynek egyik oka az lehet, hogy empirikusan nehezen különíthető el a többi dimenziótól.

\footnotetext{
${ }^{2}$ Ez a megoldás hasonlít a területi hálózatokban a csomópontok közötti távolság mérésére használt módszerhez (Jóna 2018).
}

Területi Statisztika, 2019, 59(4): 426-452; DOI: 10.15196/TS590404 
Az azonos országhoz tartozást például tekinthetjük az intézményi közelség mércéjének, mivel az azonos országban múködő vállalkozásokra azonos jogi szabályozások érvényesek, és hasonló normákat követnek (Marrocu et al. 2013). Esetünkben azonban ez nem jelent megoldást, mivel minden általunk vizsgált szervezet Magyarországon múködik. Egy másik lehetséges értelmezés, ha akkor tekintünk közelinek két szervezetet, ha azok azonos intézménytípusba tartoznak, más szóval azonos a státusuk (Ponds et al. 2007, Balland 2012, Cassi-Plunket 2015, Usai et al. 2017). Ennek értelmében az üzleti, az akadémiai és az állami szervezetek könnyebben alakítanak ki kapcsolatot az azonos csoportba tartozó intézményekkel, akikkel közös szabályozás alá esnek, és hasonló szokások jellemzik a múködésüket. Ennek alapján az azonos szervezettípusba tartozást (SameOrg) tekintjük intézményi közelségnek, és egy dummy változóval mérjük. A változó értéke 1, ha mindkét ágens vállalat, vagy mindkettő egyetem, és 0 , ha különbözőek.

\section{Társadalmi távolság}

A társadalmi közelség jelentősége abban rejlik, hogy a személyes kapcsolatok segítik a bizalom kialakulását, és csökkentik annak kockázatát, hogy a másik fél opportunista módon viselkedjen. Az interaktív tanulásban különösen fontos szerepet játszanak a bizalomra épülő kapcsolatok, mivel a tacit tudás ilyen körülmények között könynyebben terjed. Korábbi munkahelyen együtt dolgozók között megmaradhat a kapcsolat, vagy a korábbi együttmúködések során kialakulhat bizalmi kapcsolat az egyének között, ami elősegíti a későbbi együttmúködést is. Az empirikus tanulmányokban a társadalmi közelséget különböző mérőszámokkal ragadják meg, amelyek közül a legelterjedtebb az együttmúködési hálózatban elfoglalt pozíciók geodéziai távolságának inverze (Autant-Bernard et al. 2007, Balland 2012, Usai et al. 2017). Ezzel szemben Broekel és Boschma (2012) a cégek közötti együttmúködések vizsgálatakor azt tekintik társadalmi közelségnek, ha a két vállalat menedzserei korábban egy szervezetnél dolgoztak. Az utóbbi módszer esetünkben nem alkalmazható, az adatok elérhetősége és a modell logikája miatt. Számunkra ezért az a megfelelő, ha a hálózati távolságból származtatjuk a társadalmi távolságot. Mivel kétdimenziós társadalmi térben mozognak az ágensek, ezért a hálózati távolságot euklideszi távolsággá szükséges alakítani, ami alapján már elhelyezhetőek a szereplők a rendszerben. A társadalmi távolságot (SocDist) a társadalmi térben elfoglalt pozíciók közötti euklideszi távolsággal mérjük. A számítás alapjául szolgáló kapcsolati mátrixban 1-es érték szerepel, ha a két szervezet között már 2014-ben is volt kapcsolat, és 0, ha nem volt. Ebből kiszámítjuk a páronkénti hálózati távolságokat, majd az MDS módszerével azt leképezzük a kétdimenziós társadalmi térre. A társadalmi távolság tehát a hálózati távolságból származik, de nem egyezik meg vele, hanem annak a két dimenzióra leképezett mása. Azt feltételezzük, hogy a korábbi együttmúködésekből kialakuló társadalmi hálózatban a direkt és az indirekt kapcsolatok elősegítik a jövőbeli kapcsolatok kialakulását, valamint a meglévő kapcsolatok fenntartását is.

Területi Statisztika, 2019, 59(4): 426-452; DOI: 10.15196/TS590404 


\section{Az egyenlet becslése}

A különböző közelségdimenziók és az innovációs célú együttmúködések közötti kapcsolat feltárására alapvetően kétféle módszert használnak az ökonometriai elemzésekben. Abban az esetben, ha az együttmúködések száma is ismert, mint például az európai uniós keretprogram-együttműködések vagy a közös szabadalmak esetén, valamilyen count data modellt használnak, amely Poisson- vagy binomiális eloszlásból indul ki. Amikor viszont nem megszámlálható az eredményváltozó, hanem csak a kapcsolat léte, legfeljebb erőssége ismert, akkor probit vagy logit regressziót alkalmaznak (Paier-Scherngell 2011). Esetünkben is ez a helyzet, ezért bináris logit regressziót alkalmaztunk a gravitációs egyenlet paramétereinek becsléséhez.

Annak a valószínúsége, hogy kapcsolat van két szervezet között, a következő módon függ a magyarázó változók értékétől:

$$
\operatorname{Conn}_{i, j}=P_{i}=\frac{1}{1+e^{-z_{i, j}}}
$$

ahol

$$
\begin{aligned}
z_{i, j}=\beta_{0}+\beta_{1} & \cdot\left(\text { InnMass }_{i}+\text { InnMass }_{j}\right)+\beta_{2} \cdot \text { GeoDist }_{i, j}+\beta_{3} \cdot \text { TechD }_{i, j}+\beta_{4} \\
& \cdot \text { TechD }_{i, j}+\beta_{5} \cdot \text { TechD }_{i, j}+\beta_{6} \cdot \text { TechD }_{i, j}+\beta_{7} \cdot \text { SocDist }_{i, j}+\beta_{8} \\
& \cdot \text { SameOrg }_{i, j}
\end{aligned}
$$

A 2015 és 2016 fordulóján megfigyelt kapcsolatok létét magyarázzuk a független változók egy évvel korábbi hipotetikus értékével. Feltételezzük, hogy az innovatív tömeg, a technológiai közelség, az intézményi közelség és a földrajzi távolság nem változik az elemzett idôszakon belül, ezért csak a társadalmi távolság egy évvel korábbi értékére van szükségünk. Ezt úgy határozzuk meg, hogy a már egy évvel korábban is meglévő kapcsolatok alapján felírunk egy hipotetikus kapcsolati mátrixot. Ebből hálózati távolságot számítunk, amiből az optimalizálási eljárás segítségével megkapjuk a társadalmi térben elfoglalt pozíciókat, és az ezek között értelmezett euklideszi távolság jelenti a társadalmi távolságot.

A becslés során egy olyan regressziós egyenletből indulunk ki, melyben csak az ágensek mérete szerepel, majd egyesével bevonjuk a közelség, illetve távolság dimenzióit mérő változókat, kezdve a földrajzi távolsággal. Az 1. táblázatban összefoglaltuk a koefficiensek értékét, és alattuk zárójelben feltüntettük a standard hibák nagyságát. Az eredményekből kiderül, hogy a földrajzi távolságnak a kapcsolatok létrejöttére való negatív szignifikáns hatása azután is megmaradt, miután a többi közelségtípust is beépítettük a regressziós egyenletbe. A technológiai közelséget mérő 4 dummy változó közül nem mindegyik bizonyult szignifikánsnak, de mivel ezek együtt értelmezhetőek, nem célszerú kihagyni közülük azt, amelyik nem szignifikáns. Látható, hogy míg a vártnak megfelelően a társadalmi távolság egyértelmúen negatívan hat a kapcsolatok kialakulására, addig az intézményi közelség esetén feltételezett pozitív hatás nem igazolható az alkalmazott regressziós elemzéssel.

Területi Statisztika, 2019, 59(4): 426-452; DOI: 10.15196/TS590404 
Mind a modellek magyarázó ereje, mind az információs kritériumok alapján a (4) egyenlet bizonyult a leginkább alkalmasnak az ágens alapú modell paramétereinek meghatározására. A logit együtthatók közvetlenül nehezen értelmezhetőek, ezért a kiválasztott, (4) egyenletben a marginális hatásokat is feltüntettük a standard hibák alatt.

1. táblázat

\section{A gravitációs egyenlet becslési eredményei}

Regression results from estimating the gravity model

\begin{tabular}{|c|c|c|c|c|c|}
\hline Megnevezés & (1) & (2) & (3) & (4) & (5) \\
\hline $\begin{array}{l}\text { A megfigyelések } \\
\text { száma }\end{array}$ & 10404 & 10404 & 10404 & 10404 & 10404 \\
\hline \multirow{2}{*}{ Konstans } & $-5,4136^{* * *}$ & $-4,94132 * * *$ & $-5,23328^{* * *}$ & $-2,47979 * * *$ & $-2,50442^{* * *}$ \\
\hline & $(0,135484)$ & $(0,153972)$ & $(0,167774)$ & $(0,210755)$ & $(0,284908)$ \\
\hline \multirow[b]{2}{*}{ InnMass $_{i}$} & $0,262912^{* * *}$ & $0,25913 * * *$ & $0,263822^{* * *}$ & $0,231947 * * *$ & $0,232636^{* * * *}$ \\
\hline & $(0,0180924)$ & $(0,0182462)$ & $(0,0186455)$ & $\begin{array}{c}(0,0204122) \\
0,000576829\end{array}$ & $(0,0211122)$ \\
\hline \multirow[b]{2}{*}{ InnMass $_{j}$} & $0,262912^{* * *}$ & $0,25913^{* * *}$ & $0,263822 * * *$ & $0,231947 * * *$ & 0,232636 *** \\
\hline & $(0,0180924)$ & $(0,0182462)$ & $(0,0186455)$ & $\begin{array}{c}(0,0204122) \\
0,000576829\end{array}$ & $(0,0211122)$ \\
\hline \multirow[b]{2}{*}{ GeoDist $_{i j}$} & & $-0,40340 * * *$ & $-0,3685^{* * *}$ & $-0,42813^{* * *}$ & $-0,42820^{* * *}$ \\
\hline & & $(0,0778016)$ & $(0,0782538)$ & $\begin{array}{c}(0,078039) \\
-0,00106472\end{array}$ & $(0,0780462)$ \\
\hline \multirow[b]{2}{*}{ TechD1 $1_{\mathrm{ij}}$} & & & $1,54396 * * *$ & $-0,0546157$ & $-0,0608071$ \\
\hline & & & $(0,23086)$ & $\begin{array}{c}(0,261105) \\
-0,000132428\end{array}$ & $(0,265484)$ \\
\hline \multirow[b]{2}{*}{ TechD $2_{i j}$} & & & $1,95864 * * *$ & $1,88331^{* * *}$ & $1,8787^{* * *}$ \\
\hline & & & $(0,450445)$ & $\begin{array}{l}(0,497809) \\
0,0134581\end{array}$ & $(0,499292)$ \\
\hline \multirow[b]{2}{*}{ TechD $3_{\mathrm{ij}}$} & & & $-0,315881$ & $-1,12480$ & $-1,11038$ \\
\hline & & & $(0,73058)$ & $\begin{array}{c}(0,753739) \\
-0,00171218\end{array}$ & $(0,762052)$ \\
\hline \multirow[b]{2}{*}{ TechD $_{\text {ij }}$} & & & $0,594376^{* * *}$ & $0,588778^{* * *}$ & 0,585361 *** \\
\hline & & & $(0,205043)$ & $\begin{array}{c}(0,216449) \\
0,00186521\end{array}$ & $(0,218058)$ \\
\hline \multirow[b]{2}{*}{ SocDist $_{i j}$} & & & & $-1,16957 * * *$ & $-1,16983^{* * *}$ \\
\hline & & & & $\begin{array}{c}(0,088498) \\
-0,00290860\end{array}$ & $(0,0885152)$ \\
\hline \multirow{2}{*}{ SameOrg $_{i j}$} & & & & & 0,026437 \\
\hline & & & & & $(0,205724)$ \\
\hline $\begin{array}{l}\text { Korrigált } \\
\text { McFadden } \mathrm{R}^{2}\end{array}$ & 0,151275 & 0,164662 & 0,184875 & 0,321731 & 0,320787 \\
\hline Log-likelihood & $-888,7306$ & $-873,6646$ & $-703,6292$ & $-703,6375$ & $-703,6292$ \\
\hline Akaike inf. kritérium & 1783,461 & 1755,329 & 1712,855 & 1425,275 & 1427,258 \\
\hline
\end{tabular}

Megjegyzés: Függő változó: ágenspáronkénti innovációs kapcsolat (Connij). A legjobbnak tekintett egyenlet oszlopát szürke háttérrel jelöltük. A csillagok száma a becsült együtthatók szignifikanciáját jelöli: * 10\%-os, ** 5\%-os és *** 1\%-os szinten szignifikáns együtthatót jelez.

Területi Statisztika, 2019, 59(4): 426-452; DOI: 10.15196/TS590404 
A legjobb modell magyarázó ereje közepesen erősnek tekinthető $(0,32)$, viszont az ismertetetteken kívül valószínúleg vannak még kihagyott változók, amelyek szintén befolyásolják a kapcsolatok kialakulását. Ezen kívül a torzítás abból adódhat, hogy egy erősen szelektív mintán készítettük a becslést, és nem tudjuk, hogy a válaszadók mennyiben térnek el a populáció többi tagjától. A robusztusság vizsgálataként elvégeztük a becslést a 207 szervezetet tartalmazó teljes mintára is, mivel az, hogy csak az összefüggő részt használjuk a modellben, endogén szelekcióhoz vezethet. Ebben az esetben nem tudtuk a társadalmi távolságot a kétdimenziós társadalmi térben való távolságként értelmezni, mivel a lehetséges kapcsolatok 80\%-ában (42 849-ből 34368 esetben) nincs sem közvetlen, sem közvetett kapcsolat a szervezetek között, ezért végtelen közöttük a legrövidebb út hossza, vagyis a hálózati távolság. Ha ezt próbálnánk leképezni két dimenzióra, az ágensek nagy része véletlenszerúen helyezkedne el egymáshoz képest. Ehelyett a végtelen értékeket egy nagy számmal (100) helyettesítettük, és a hálózati távolsággal becsültünk egy hasonló regressziós modellt. A 2. táblázatban összehasonlítjuk a három modellt. A korábban bemutatott, kiválasztott I. egyenlet, amelyben a társadalmi távolság szerepel, és a 102 ágenst tartalmazó összefüggő hálózatra vonatkozik, a II. egyenletet szintén csak az összefüggő hálózat adatain becsültük, de a társadalmi távolság helyett a hálózati távolság szerepel benne, mivel ez már közvetlenül összehasonlítható a III. egyenlettel, amelyet a 207 szervezetből álló teljes mintán becsültünk. Azt láthatjuk, hogy az eredetileg szignifikáns változók a teljes mintán becsült modellben is szignifikánsak maradtak, és az elójelük is változatlan. Míg a földrajzi távolság jelentősége alacsonyabb a teljes mintán, addig a hálózati távolságé magasabb. Ezen kívül a technológiai közelséghez tartozó változók paramétereiben láthatunk némi különbséget. Öszszességében nincs ellentmondás a szignifikáns változók előjelében, viszont a koefficiensek néhol eltérnek.

\section{A robusztusságvizsgálat eredményei}

2. táblázat

Results of the robustness test

\begin{tabular}{|c|c|c|c|c|}
\hline Megnevezés & I. & Megnevezés & II. & II. \\
\hline A megfigyelések száma & 10404 & A megfigyelések száma & 10404 & 42849 \\
\hline Konstans & $-2,4798^{* * *}$ & Konstans & $-5,0553 * * *$ & $-4,1110^{* * *}$ \\
\hline InnMass & $0,2319 * * *$ & InnMass & $0,2517 * * *$ & $0,2014 * * *$ \\
\hline InnMass & $0,2319 * * *$ & InnMass & $0,2517 * * *$ & $0,2014 * * *$ \\
\hline GeoDist & $-0,4281^{* * *}$ & GeoDist & $-0,2489 * * *$ & $-0,1552^{* *}$ \\
\hline TechD1 & $-0,0546$ & TechD1 & $1,4622^{* * *}$ & $0,9727 * * *$ \\
\hline TechD2 & $1,8833^{* * *}$ & TechD2 & $2,0229 * * *$ & $1,6112^{* * *}$ \\
\hline TechD3 & $-1,1248$ & TechD3 & 0,0532 & 0,6346 \\
\hline TechD4 & $0,5888^{* * *}$ & TechD4 & $0,5799 * * *$ & $0,4932 * * *$ \\
\hline SocDist & $-1,1696^{* * *}$ & NetDist & $-0,01688 * * *$ & $-0,0529 * * *$ \\
\hline
\end{tabular}

Területi Statisztika, 2019, 59(4): 426-452; DOI: 10.15196/TS590404 
$\mathrm{Az}$ ismertetettek alapján megállapítható, hogy ugyan nem érdemes általánosítani a kapott eredményeket, és messzemenő következtetéseket levonni a közelségtípusok marginális hatásairól, de a becslés a célunknak megfelel, miszerint lehetővé teszi az ágens alapú modell paramétereinek meghatározását.

\section{Az ágens alapú modell kalibrációja}

A fennmaradó paraméterek értékét kalibrálás útján határozzuk meg. Ide tartoznak az ágensek mozgását befolyásoló, heterogenitást biztosító paraméterek: a partnerlista hossza $(A P)$, a sebesség alap- $(\bar{S})$ és elaszticitásparamétere $(S R)$, valamint az ellenerő alap- $(\overline{B F})$ és elaszticitásparamétere $(B R)$. Mivel csak keresztmetszeti adatok állnak rendelkezésünkre, de célunk a dinamikus elemzés, ezért szükség van a társadalmi térben elfoglalt korábbi hipotetikus pozíciók meghatározására, amelyból elindítva a szimulációt a modell dinamikájának köszönhetően eljutunk a megfigyelt állapotba. Ennek érdekében az ágenseket a már 2010-ben is meglévő kapcsolataik alapján helyezzük el a társadalmi térben. Meghatározunk egy küszöbértéket, amit ha meghalad a két ágens közötti becsült vonzerő, akkor közöttük kapcsolat alakul ki. Ezt az értéket úgy állítjuk be, hogy pontosan eltaláljuk a hipotetikus kezdeti állapotban az öszszes kapcsolat számát. A modell kalibrálandó paramétereit úgy határozzuk meg, hogy a szimuláció a lehetô legpontosabban megközelítse a hipotetikus kiindulási helyzetből a 2016-ban megfigyelt kapcsolati hálót.

Az illeszkedés mérésénél két szempontot veszünk figyelembe, és ennek megfelelően kétféle mérôszám szerint optimalizálunk:

- A szimuláció eredményeként adódó páronkénti kapcsolatok a lehető legközelebb essenek a megfigyelt páronkénti kapcsolatokhoz:

$$
F=\frac{\sum_{i=1}^{n} \sum_{j=1}^{n}\left|c_{i j}-a_{i j}\right|}{n^{2}}
$$

ahol $c_{i j}$ a megfigyelt kapcsolati mátrix egy eleme, $a_{i j}$ pedig a szimulált mátrix elemét jelöli.

- Az összes szimulált kapcsolat száma a lehető legközelebb essen az összes megfigyelt kapcsolat számához:

$$
F_{\text {sum }}=\frac{\left|\sum_{i=1}^{n} \sum_{j=1}^{n} c_{i j}-\sum_{i=1}^{n} \sum_{j=1}^{n} a_{i j}\right|}{\sum_{i=1}^{n} \sum_{j=1}^{n} c_{i j}}
$$

A két mutatót azonos súllyal vesszük figyelembe a paraméterek kalibrálása során. Mindkét mutató a tényleges állapottól való eltérést ragadja meg, ezért ezek összegének minimalizálásával kapjuk meg azt a paraméterkombinációt, amely mellett a szimulált állapot a legjobban megközelíti a megfigyeltet. Az optimalizációs folyamat végére a kapcsolatok számának összegére vonatkozó eltérés gyakorlatilag 0-val egyenlő, a kapcsolati mátrix elemeiben való eltérés értéke pedig 0,0305. A 3. táblázatban látható, hogy az egyes paraméterek esetén milyen intervallumon történt az optimalizáció, valamint az is, hogy végül mennyi lett az optimális érték.

Területi Statisztika, 2019, 59(4): 426-452; DOI: 10.15196/TS590404 
A kalibrált paraméterek értékei

3. táblázat

Values of the calibrated parameters

\begin{tabular}{l|c|c|c}
\hline \multicolumn{1}{c|}{ Paraméter } & Jel & Intervallum & Optimális érték \\
\hline Az ágensek sebességének alapparamétere & $\bar{S}$ & {$[0 ; 0,1]$} & 0,076802 \\
Az ellenerő alapparamétere & $\overline{B F}$ & {$[0 ; 1]$} & 0,64178 \\
A partnerlista hossza & $A P$ & {$[0 ; 101]$} & 5 \\
A sebesség elaszticitásparamétere & $S R$ & {$[-1 ; 1]$} & 0,010456 \\
Az ellenerő elaszticitásparamétere & $B R$ & {$[-1 ; 1]$} & $-0,084521$
\end{tabular}

\section{Szakpolitikai szimuláció}

Ebben a fejezetben azt szemléltetjük, hogy hogyan lehet a szakpolitikai beavatkozások hatását szimulálni az előbbiekben ismertetett ágens alapú modellel. Ennek érdekében a 2. ábrán bemutatjuk a szimuláció múködését.

\section{A szimuláció működése}

Functioning of the simulation model

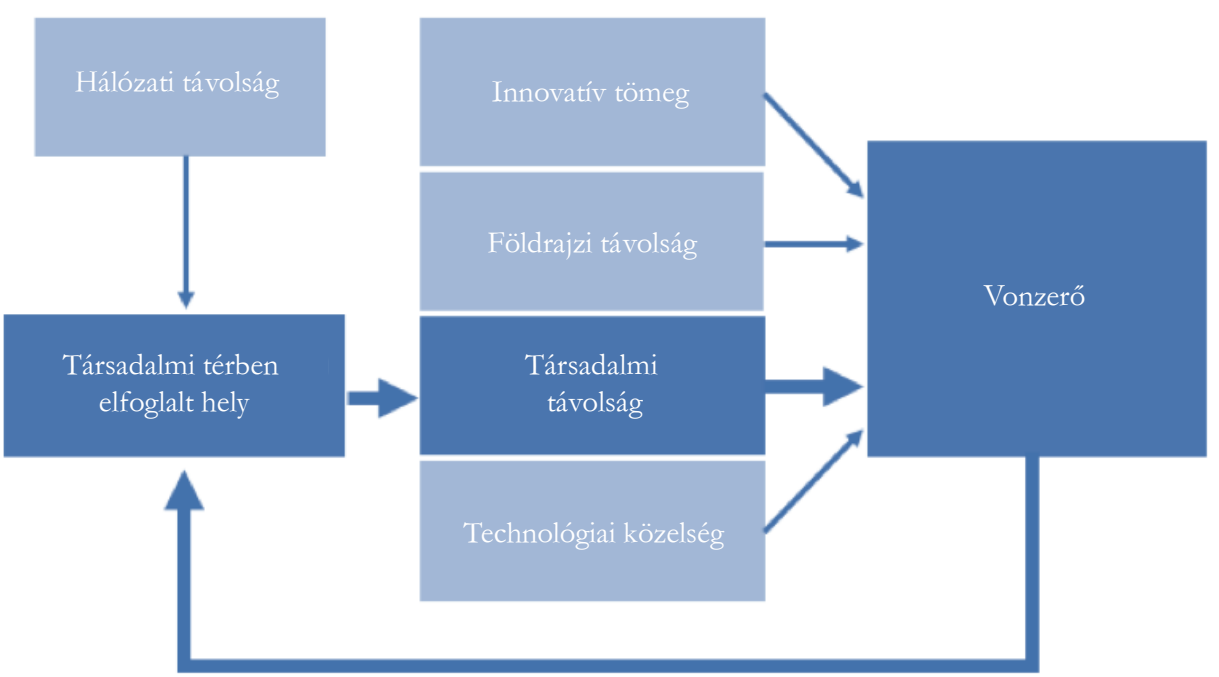

A kétdimenziós társadalmi térben elfoglalt kezdeti pozíció az ágensek hálózati távolságából származik, és meghatározza a közöttük lévő társadalmi távolságot. Az innovatív tömeg, a földrajzi távolság, a társadalmi távolság és a technológiai közelség

Területi Statisztika, 2019, 59(4): 426-452; DOI: 10.15196/TS590404 
együttesen determinálják az ágensek közötti vonzerőt, a gravitációs egyenletnek megfelelően. Ha ezek közül bármelyik megváltozik, akkor a páronkénti vonzerő módosul, és ennek hatására az ágensek elmozdulnak a számukra vonzó társaik irányába. Ennek következtében megváltozik a társadalmi térben elfoglalt pozíciójuk, amely által a társadalmi távolságuk is, ́́gy a közöttük lévő vonzerő újra módosul, ami visszahat a társadalmi térbeli pozíciókra. Ez a folyamat tartja mozgásban a rendszert, de egy idő után a modell stacioner jellege miatt beáll egy új egyensúlyi állapot.

Jelenleg Európában az intelligens szakosodás elvei (Foray 2015, McCannOrtega-Argliés 2015) nagy hatással vannak a szakpolitikai koncepció kialakítására. Az intelligens szakosodási stratégia kidolgozása során a prioritások meghatározásában nyújthat segítséget egy ilyen szimuláció, ugyanis még a szakpolitikai beavatkozások implementálása előtt megvizsgálható, hogy az adott szektor támogatása várhatóan mennyiben járulna hozzá az innovációs hálózat súrűsödéséhez.

Míg a kalibrációs időszak a 2010 és 2016 közötti intervallum, addig a szakpolitikai szimulációt a megfigyelt állapothoz képest előre vetítjük, ennek megfelelően a 2016-ban megfigyelt helyzetből indítjuk a szimulációt. Az alapforgatókönyvben a megfigyelt 102 szervezet alkotta hálózat szerepel. Ehhez hasonlítjuk az alternatív forgatókönyvet, amelyben 3 új cég lép be a hálózatba, amelyekről feltesszük, hogy központjuk Budapesten helyezkedik el, és egy, a térségben prioritással rendelkező ágazatban tevékenykednek. Az új belépők egyetlen kapcsolattal rendelkeznek, egy szintén budapesti céggel, amellyel azonos szakágazatba tartoznak. A vizsgált szektort úgy választottuk ki, hogy a Nemzeti Intelligens Szakosodási Stratégiába (Nemzeti Innovációs Hivatal 2014) foglaltak szerint beletartozzon Budapest és Pest megye intelligens technológiái közé. Egy megye intelligens szakosodási iránya két részből tevődik össze: a nemzeti prioritásokból és az intelligens technológiákból. Az előbbiek olyan szakosodási irányokat jelölnek, amelyek minden megye számára meghatározóak, a második kategóriába ezzel szemben azok a specializációs irányok tartoznak, amelyek egy-egy intelligens technológiához kötődnek, de csak bizonyos megyékben relevánsak. Ilyen Budapesten és Pest megyében többek között az építóipar, amelyet a 71-es TEÁOR-kóddal jelölt, „Építészmérnöki tevékenység; műszaki vizsgálat, elemzés" ágazattal azonosítottunk. Ide sorolható az elemzésbe bevont több budapesti cég is, tehát a mintánk szerint is megvan a szektor mögött a kritikus tömeg, ami szükséges ahhoz, hogy intelligens specializációs irány válhasson belóle.

A 3. ábrán az alap- és a szakpolitikai forgatókönyv eredményét hasonlítjuk össze. A vízszintes tengelyen a szimulációs lépések találhatók, amelyek nem egyeznek meg a naptári évekkel. A 2016-ban megfigyelt adatok szerint a 102 vizsgált szervezet között 108 kapcsolat létesült, ezt tekintjük a szimuláció kiindulópontjának. Az ábráról leolvasható, hogy a 3 új cég belépése az építóiparba hosszú távon jelentősen megnöveli a vizsgált szervezetek közötti innovációs együttmúködések számát. A kezdeti 108 kapcsolathoz képest hosszú távon 157-re nő a kapcsolatok száma a 
hálózaton belül, ha nem történik beavatkozás, és 171-re, ha 3 új cég belép a hálózatba, kezdetben csak egy-egy kapcsolattal.

\section{A kapcsolatok számának alakulása}

3. ábra a magyar high-tech gazellák hálózatában

Number of ties in the network of Hungarian high-tech gazelles

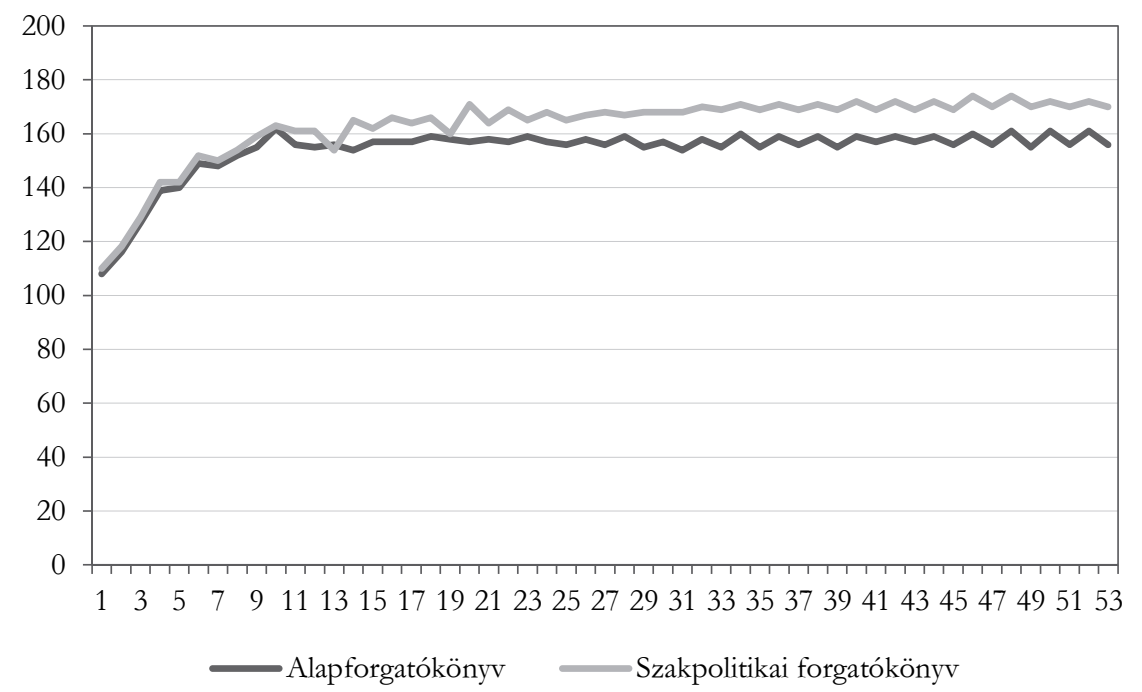

Mivel az új belépők a lehetséges kapcsolatok számára is hatással vannak, ezért nem tekinthetünk a kapcsolatok számának növekedésére automatikusan a sűrűség növekedéseként is. A hálózat sûrûségét $(D)$ meghatározhatjuk a tényleges élek számának $(E)$ és az összes lehetséges él ( $\left.E_{\max }\right)$ számának hányadosaként:

$$
D=\frac{E}{E_{\max }}
$$

ahol az elméletileg lehetséges összes él száma a csúcsok számától $(N)$ függően a következőképpen adódik:

$$
E_{\max }=\frac{(N \cdot(N-1))}{2}
$$

A 4. táblázatból látható, hogy a 3 új belépő következtében a hálózat sűrűsége is magasabb lesz annál, mintha azok nem léptek volna be. Mindez annak ellenére alakult így, hogy kezdetben a lehetséges kapcsolatok számának növekedése miatt a 3 új belépő esetén alacsonyabb volt a hálózat sűrűsége, mint az alapforgatókönyvben.

Területi Statisztika, 2019, 59(4): 426-452; DOI: 10.15196/TS590404 
Az innovációs hálózat jellemzői forgatókönyvek szerint

Characteristics of the innovation network by scenarios

\begin{tabular}{l|l|l}
\hline \multirow{2}{*}{ Forgatókönyv } & \multicolumn{2}{|c}{ A szimuláció } \\
\cline { 2 - 3 } & \multicolumn{1}{|c}{ kezdetén } & \multicolumn{1}{c}{ végén } \\
\hline Alapforgatókönyv & $N=102$ & $N=102$ \\
& $E=108$ & $E=157$ \\
& $E_{\max }=5151$ & $E_{\max }=5151$ \\
& $\boldsymbol{D}=\mathbf{0 , 0 2 1 0}$ & $\boldsymbol{D}=\mathbf{0 , 0 3 0 5}$ \\
\hline Szakpolitikai forgatókönyv & $N=105$ & $N=105$ \\
& $E=111$ & $E=171$ \\
& $E_{\max }=5460$ & $E_{\max }=5460$ \\
& $\boldsymbol{D}=\mathbf{0 , 0 2 0 3}$ & $\boldsymbol{D}=\mathbf{0 , 0 3 1 3}$
\end{tabular}

Megjegyzés: $N$ - a csomópontok száma, $E$ - a köztük lévő élek száma, $E_{\max }$ - a lehetséges élek száma, $D$ - a hálózat sűrűsége.

\section{Konklúzió és a vizsgálat korlátai}

Tanulmányunkban ágens alapú modell segítségével szimuláltuk a közelség dimenzióinak és az innovációs hálózatnak a kapcsolatát. A szakirodalomhoz 3 fő ponton járul hozzá a magyar gazellák hálózatának az előzőekben bemutatott modellje. Egyrészt a különböző közelségtípusok és az innovációs együttmúködések kapcsolatát vizsgáló legtöbb tanulmánnyal ellentétben, amelyekben a formális kapcsolatok vizsgálatára szorítkoznak, az innovációs kapcsolatok széles körét tudtuk vizsgálni a kérdőíves adatfelvételnek köszönhetően. Másrészt, a szakirodalomban uralkodó statikus szemlélettel szemben dinamikus megközelítést alkalmaztunk, és szimuláltuk a hálózat formálódását. Ezen felül a társadalmi távolság endogén módon való alakulásán keresztül a közelség és a tudáshálózat egymásra való hatását is modelleztük. Harmadrészt bemutattuk, hogy hogyan lehet szakpolitikai szimulációt végezni ágens alapú modell segítségével. A szakpolitikai szimuláció következtetése, hogy néhány, de a térség intelligens szakosodási irányába tartozó ágazatba belépő új cég a hazai szervezetek közötti innovációs együttmúködések számát, ezáltal a hálózat sűrűségét képes jelentősen növelni.

Vizsgálatunkat számottevően korlátozta egyrészt az, hogy csupán keresztmetszeti adatok álltak rendelkezésünkre, ami miatt a modell kalibrálásához egy hipotetikus kiindulóhelyzetet kellett létrehoznunk, ami nagy valószínűséggel nem egyezik meg a tényleges korábbi helyzettel. Másrészt egy szelektív mintán végeztük az elemzést, ezért az ökonometriai eredményeink torzítottak lehetnek, és a következtetéseinket nem vonatkoztathatjuk a teljes sokaságra. A magyar cégek és egyéb szervezetek 
innovációs együttmúködési hálózatának egy szúk szegmensét, amely a high-tech gazellák köré szerveződik, azonban részletesen megismerhettük. Annak ellenére, hogy az eredmények nem általánosíthatók, a tanulmány hozzájárul a különböző közelségdimenziók szerepének komplex megítéléséhez, továbbá a közelségdimenziók, valamint az innovációs hálózat kölcsönös egymásra hatásának megértéséhez. Reprezentatív mintavétellel és paneladatok használatával olyan eredményekre juthatnánk, amelyekre alapozva megbízhatóbb és nagyobb mértékben általánosítható szakpolitikai elemzések végezhetők.

\section{Köszönetnyilvánítás}

Jelen publikáció az Európai Unió, Magyarország és az Európai Szociális Alap társfinanszírozása által biztosított forrásból az EFOP-3.6.2-16-2017-00017 azonosítójú „Fenntartható, intelligens és befogadó regionális és városi modellek" címú projekt keretében jött létre. Varga-Csajkás Anna továbbá köszönetét fejezi a Pallas Athene Domus Educationis Alapítvány anyagi támogatásáért.

\section{IRODALOM}

Ahrweiler, P.-PYKA, A.-GilBerT, N. (2004): Simulating knowledge dynamics in innovation networks (SKIN). Volkswirtschaftliche Diskussionsreihe. Institut für Volkswirtschaftslehre der Universität Augsburg, Augsburg. https://doi.org/10.1142/9789812702258_0014

Autant-Bernard, C.-Billand, P.-Frachisse, D.-Massard, N. (2007): Social distance versus spatial distance in R\&D cooperation: empirical evidence from European collaboration choices in micro and nanotechnologies Papers in Regional Science 86 (3): 495-519. https://doi.org/10.1111/j.1435-5957.2007.00132.x

BALland, P. A. (2012): Proximity and the evolution of collaboration networks: evidence from research and development projects within the global navigation satellite system (GNSS) industry Regional Studies 46 (6): 741-756. https://doi.org/10.1080/00343404.2010.529121

Balland, P-A.-Boschma, R.-Frenken, K. (2014): Proximity and innovation: From statics to dynamics Regional Studies 49 (6): 907-920. https://doi.org/10.1080/00343404.2014.883598

BARABÁsI, A. L.-AlBERT, R. (1999): Emergence of Scaling in Random Networks Science 286 (5439): 509-512. https://doi.org/10.1126/science.286.5439.509

BÉKÉS, G.-MurAKÖZY, B. (2012): Magyar gazellák. A gyors növekedésű vállalatok jellemzői és kialakulásuk elemzése Közgazdasági Szemle 59 (3): 233-262.

Birch, D. L.-Medoff, J. (1994): Gazelles In: Solmon L. C.-Levenson, A. R. (Eds.) Labor Markets, Employment Policy and Job Creation pp. 159-167., Boulder, CO and Westview Press, London.

Boschma, R. (2005): Proximity and innovation: a critical assessment Regional Studies 39 (1): 61-74. https://doi.org/10.1080/0034340052000320887

Boschma, R.-Frenken, K. (2010): The spatial evolution of innovation networks. A proximity perspective In: BOSCHMA, R.-MARTIN, R. (Eds): The handbook of

Területi Statisztika, 2019, 59(4): 426-452; DOI: 10.15196/TS590404 
evolutionary economic geography pp. 120-135., Edward Elgar Publishing, Cheltenham, UK. https://doi.org/10.4337/9781849806497.00012

Broekel, T.- Boschma, R. (2012): Knowledge networks in the Dutch aviation industry: the proximity paradox Journal of Economic Geography 12 (2): 409-433. https://doi.org/10.1093/jeg/lbr010

CANTNER, U.-MEDER, A. (2007): Technological proximity and the choice of cooperation partner Journal of Economic Interaction and Coordination 2 (1): 45-65. https://doi.org/10.1007/s11403-007-0018-y

CAPONE, F.-LAZZERETTI, L. (2018): The different roles of proximity in multiple informal network relationships: evidence from the cluster of high technology applied to cultural goods in Tuscany Industry and Innovation 25 (9): 897-917. https://doi.org/10.1080/13662716.2018.1442713

CASSI, L.-PLUNKET, A. (2015): Research collaboration in co-inventor networks: combining closure, bridging and proximities Regional Studies 49 (6): 936-954. https://doi.org/10.1080/00343404.2013.816412

CsAPÓ, K. (2011): The Characteristics and Development Possibilities of Fast-Growing Small and Medium-Sized Companies in Hungary ERENET PROFILE 6 (3): 16-27.

D'EsTe, P.-GuY, F.-IAMMARINO, S. (2013): Shaping the formation of university-industry research collaborations: what type of proximity does really matter? Journal of Economic Geography 13 (4): 537-558. https://doi.org/10.1093/jeg/lbs010

ERDŐs, P.-RÉNYI, A. (1959): On Random Graphs Publicationes Mathematicae 6: 290-297.

FORAY, D. (2015): Smart specialization. Opportunities and challenges for regional innovation policy Routledge, London and New York.

GilberT, N.-PyKA, A.-AHrweILER, P. (2001): Innovation networks - a simulation approach Journal of Artificial Societies and Social Simulation 4 (3): 1-13.

GuI, Q.-LIU, C.-DU, D. (2018): International knowledge flows and the role of proximity Growth and Change 49 (3): 532-547. https://doi.org/10.1111/grow.12245

Hau-Horváth, O.-Horváth, M. (2014): A földrajzi közelség szerepe az innovációs együttműködésekben-illúzió vagy valós tényező? Közgaẓdasági Szemle 61 (12): 1419-1446.

Hau-Horváth, O.-Sebestyén, T.-VARGA, A. (2016): Tudáshálózatok szerepe a regionális fejlődésben-egy integrált modell alkalmazásának tapasztalatai a magyar régiók esetében Statištikai Szemle 94 (2): 117-142. https://doi.org/10.20311/stat2016.02.hu0117

Havnes, P-A.-SEnNeseth, K. (2001): A panel study of firm growth among SMEs in networks Small business economics 16 (4): 293-302. https://doi.org/10.1023/A:1011100510643

Heshmati, A.-LEnZ-Cesar, F. (2013): Agent-based simulation of cooperative innovation in R\&D Research Evaluation 22 (1): 15-29. https://doi.org/10.1093/reseval/rvs032

JaCKSON, M. O. (2005): A Survey of Models of Network Formation: Stability and Efficiency In: Demange, G.-WoOders, M. (eds.): Group Formation in Economics: Networks, Clubs, and Coalitions pp. 11-49., Cambridge University Press, Cambridge, UK.

JÓNA, GY. (2018): A gazdasági hálózatok komplex területi teljesítményének mérése Területi Statisztika 58 (4): 380-398. https://doi.org/10.15196/TS580403

Területi Statisztika, 2019, 59(4): 426-452; DOI: 10.15196/TS590404 
Korber, M.-PAier, M. (2011): Exploring the Effects of Public Research Funding on Biotech Innovation: An Agent-Based Simulation Approach Paper presented at the Proceedings of the Eighth International Conference on Complex Systems "Unifying Themes in Complex Systems", 26 June-1 July 2011, Boston, Quincy, MA, USA.

Korber, M.-PAiER, M. (2013): Effects of Competence Centres on Regional Knowledge Production: An Agent-Based Simulation of the Vienna Life Sciences Innovation System In: SCHERNGELL, T. (ed.) The Geography of Networks and R\&D Collaborations pp. 353-371., Springer, Berlin-Heidelberg-New York.

LECHNER, C.-DOWLING, M. (2003): Firm networks: external relationships as sources for the growth and competitiveness of entrepreneurial firms Entrepreneurship \& Regional Development 15 (1): 1-26. https://doi.org/10.1080/08985620210159220

MagGioni, M. A.-UberTi, T. E. (2009): Knowledge networks across Europe: which distance matters? The Annals of Regional Science 43 (3): 691-720. https://doi.org/10.1007/s00168-008-0254-7

Marrocu, E.-PACI, R.-USAI, S. (2013): Proximity, networking and knowledge production in Europe: What lessons for innovation policy? Technological Forecasting and Social Change 80 (8): 1484-1498. https://doi.org/10.1016/j.techfore.2013.03.004

Marshall, A. (1920/1890): Principles of Economics An Introductory Volume. 8 Macmillan and Co., London.

McCann, P.-OrtegA-Argilés, R. (2015): Smart Specialization, Regional Growth and Applications to European Union Cohesion Policy Regional Studies 49 (8): 12911302. https://doi.org/10.1080/00343404.2013.799769

MTA-PTE Innováció és Gazdasági Növekedés Kutatócsoport (2014): Magyar gazella cégek együttmüködési hajlandóságának vizsgálata Pécs.

MTA-PTE Innováció és Gazdasági Növekedés Kutatócsoport (2016): Kutatási jelentés. Gažllakutatás második és harmadik kör Pécs.

NÉMETHNÉ, P. (2010). Hol szökellnek a magyar gazellák?-A dinamikusan növekvő kis- és középvállalatok néhány jellemzője Vezetéstudomány/Budapest Management Review 41 (4): 32-44.

PAier, M.-SCHERngell, T. (2011): Determinants of collaboration in European R\&D networks: empirical evidence from a discrete choice model Industry and Innovation 18 (1): 89-104. https://doi.org/10.1080/13662716.2010.528935

PAier, M.-DünSer, M.-Scherngell, T.-MARTin, S. (2017): Knowledge creation and research policy in science-based industries: an empirical agent-based model In: Vermeulen, B.-PAIER, M. (eds): Innovation Networks for Regional Development. Economic Complexity and Evolution pp. 153-183., Springer, Cham. https://doi.org/10.1007/978-3-319-43940-2_7

PAPANEK, G. (2010): A gyorsan növekvő magyar kis-és középvállalatok a gazdaság motorjai Közgazdasági Szemle 57 (4): 354-370.

PONDS, R.-VAN OORT, F.-FrENKEN, K. (2007): The geographical and institutional proximity of research collaboration Papers in Regional Science 86 (3): 423-443. https://doi.org/10.1111/j.1435-5957.2007.00126.x

PYKA, A.-SAVIOTTI, P. (2002): Innovation networks in the biotechnology-based sectors PYKA, A.-KupPers, G. (Eds.) Innovation Networks: Theory and Practice pp. 75-107. Edward Elgar Publishing, Cheltenham.

Területi Statisztika, 2019, 59(4): 426-452; DOI: 10.15196/TS590404 
PykA, A.-GilberT, N.-AhrweIleR, P. (2007): Simulating knowledge-generation and distribution processes in innovation collaborations and networks Cybernetics and Systems: An International Journal 38 (7): 667-693. https://doi.org/10.1080/01969720701534059

PyKA, A.-Mueller, M.-KudiC, M. (2018): Regional Innovation Systems in Policy Laboratories Journal of Open Innovation: Technology, Market, and Complexity 4 (4): 44. https://doi.org/10.3390/joitmc4040044

SCHERNGELL, T.-BARBER, M. J. (2009): Spatial interaction modelling of cross-region R\&D collaborations: empirical evidence from the 5th EU framework programme Papers in Regional Science 88 (3): 531-546. https://doi.org/10.1111/j.14355957.2008.00215.x

Schoonjans, B.-Van Cauwenberge, P.-Vander Bauwhede, H. (2013): Formal business networking and SME growth Small Business Economics 41 (1): 169-181. https://doi.org/10.1007/s11187-011-9408-6

SEBESTYÉN, T.-VARGA, A. (2019): Knowledge networks in regional development. An agent based model and its application. Regional Studies (forthcoming)

SzERB, L.-KOMLÓsI, É.-VARGA, A. (2017): Gyors növekedésű vállalatok Magyarországon: Az innovatív, a rejtélyes és a virtuális gazellák Közgazdasági Szemle 64 (5): 476-506. http://dx.doi.org/10.18414/KSZ.2017.5.476

Usai, S.-MARrocu, E.-PACI, R. (2017): Networks, Proximities, and Interfirm Knowledge Exchanges International Regional Science Review 40 (4): 377-404. https://doi.org/10.1177/0160017615576079

VARGA, A.-SEBESTYÉN, T. (2017): A hálózati és a lokalizált tudásáramlás különbségei Európában Területi Statisz̧tika 57 (1): 24-51. https://doi.org/10.15196/TS570102

Watts, D. J.-Strogatz, S. H. (1998): Collective Dynamics of 'Small-World' Networks Nature 393: 440-442. https://doi.org/10.1038/30918

ZENG, S. X.-XIE, X. M.-TAM, C. M. (2010): Relationship between cooperation networks and innovation performance of SMEs Technovation 30 (3): 181-194. https://doi.org/10.1016/j.technovation.2009.08.003

\section{INTERNETES HIVATKOZÁS}

Nemzeti InNovációs Hivatal (2014): Nemzeti Intelligens Szakosodási Stratégia Budapest. (letöltve: 2019. január) https://nkfih.gov.hu/szakpolitika-strategia/nemzetistrategiak/nemzeti-intelligens\# 